YEARBOOK of ANTITRUST and REGULATORY STUDIES www.yars.wz.uw.edu.pl
Peer-reviewed scientific periodical, focusing on legal and economic issues of antitrust and regulation. Creative Commons Attribution-No Derivative Works 3.0 Poland License.

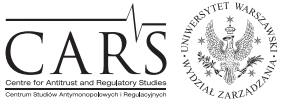

Centre for Antitrust and Regulatory Studies, University of Warsaw, Faculty of Management www.cars.wZ.uw.edu.pl

\title{
Institutional Challenges for Private Enforcement of Competition Law in Central and Eastern European Member States of the EU
}

\author{
by
}

Ondrej Blažo*

\section{CONTENTS}

I. Introduction

II. Requirements for national judicial systems described in the Damages Directive

III. Specialization of courts - general observations

IV. Specialization, centralization and generalized approach in CEE Member States

V. Relationship between courts and NCAs

VI. Conclusions

\section{Abstract}

The paper will focus on requirements and thresholds set for the judiciary by the Damages Directive. Answered will also be questions on the specialization of courts and its application in Central and Eastern European (CEE) Member States of the $\mathrm{EU}$, as well as on the involvement of national competition authorities (NCAs) in court proceedings. The paper provides also general thoughts regarding the specialization of courts and confronts them with the judiciary structure in CEE Member States in the context of private enforcement of competition law. While there is no uniform model of a judicial system, the paper provides a critical analysis of the centralization, specialization and decentralization of private enforcement models, taking into account also the importance of the training of judges. The

* JUDr. Ing., PhD, Comenius University in Bratislava, Faculty of Law, Institute of European Law; ondrej.blazo@flaw.uniba.sk. Paper was prepared within the grant project APVV-0158-12 'Effectiveness of legal regulaiton of copetition in the context of its application in practice'. Article received: 11.08.2017; accepted: 31.08.2017. 
relationship between NCAs and courts will be discussed whereby the role of NCAs in private enforcement defines the responsibility of the given public authority in private enforcement as a country's policymaker.

\section{Résumé}

L'article se concentre sur les exigences et les seuils fixés par la Directive Dommages pour le pouvoir judiciaire. Les réponses vont se focaliser également sur la spécialisation des tribunaux et son application dans les États membres

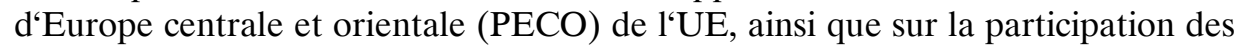
autorités nationales de concurrence (ANC) aux procédures judiciaires. Larticle fournit également des réflexions générales sur la spécialisation des tribunaux et les confronte à la structure judiciaire des États membres de l'Europe centrale et orientale dans le cadre de l'application privée du droit de la concurrence. Bien qu'il n'existe pas de modèle uniforme de système judiciaire, l'article fournit une analyse critique de la centralisation, de la spécialisation et de la décentralisation des modèles d'application privée du droit de la concurrence, en tenant également compte de l'importance de la formation des juges. La relation entre les ANC et les tribunaux sera examinée dans le contexte ou le rôle des ANC dans l'application privée du droit de la concurrence définit la responsabilité d'autorité publique comme un décideur politique national.

Key words: judicial system; judicial specialization; competition law; damages; harmonization; EU law.

JEL: K40; K21

\section{Introduction}

In the European Union, specific judicial systems are subject to their national regulation and Member States employ different models in this context. EU law usually gives only general guidelines to secure the rule of law and to empower courts with a specific authority to enforce common EU policies required by respective legislation.

Directive 2014/104/EU of the European Parliament and of the Council of 26 November 2014 on certain rules governing actions for damages under national law for infringements of the competition law provisions of the Member States and of the European Union ${ }^{1}$ (hereinafter, 'Damages Directive') introduces a set of powers to be granted to 'national courts', for example,

1 OJ L 349, 05.12.2014. 
rules on disclosure of evidence, power to impose penalties, cooperation with national competition authorities (hereinafter, 'NCAs'). However, the Damages Directive does not bind Member States regarding the detailed structure and types of the courts or tribunals responsible for dealing with damages claims.

The paper will focus on (1) requirements and thresholds set for the judiciary by the Damages Directive, (2) questions of the specialization of courts and (3) its application in CEE Member States as well as (4) the role of NCAs in court proceedings.

\section{Requirements for national judicial systems described in the Damages Directive}

The scope of the Damages Directive regarding bodies empowered to handle private enforcement cases is quite limited. The Damages Directive covers procedural powers of 'national courts' with respect to private enforcement, while referring to the meaning of the term 'court or tribunal' provided under Article 267 TFEU. ${ }^{3}$ While describing its own scope as coordination of 'the enforcement of the competition rules by competition authorities and the enforcement of those rules in damages actions before national courts', ${ }^{4}$ the Damages Directive remains silent on the powers of other bodies and tribunals that can be involved in private enforcement (for example, ADR, administrative bodies). As it is obvious from the spirit of the Damages Directive (as well as its limited scope), the Damages Directive represent a 'minimum standard' form of harmonization, and so it does not offset national regulations that provide more rights, enhance safeguards and provide more effective enforcement. The Damages Directive thus does not prevent Member States from empowering bodies and tribunals other than 'national courts' with rights similar to those of 'national courts' described in the Damages Directive. On the other hand, this enhancement of powers cannot undermine effective public enforcement. However, neither the Damages Directive nor its preparatory documents answer

2 Damages Directive, Art. 2(9).

3 There is a lot of literature and discussions as well as developed case-law dealing with the concept of 'court' or 'tribunal' and for the purposes of this paper it is not necessary to analyse this concept, (for instance Ježová, 2013, p. 35-38; Stehlík, 2006, p. 30; Stehlík, 2005, Steiner and Woods, 2009, p. 229; Judgment of 30.06.1966, Case C-61/65 Vaassen-Goebbels v. Beambtenfonds voor het Mijnbedrijf, ECLI:EU:C:1966:39; Judgment of 11.06.1987, Case C-14/86 Pretore di Salò v. Persons unknown, ECLI:EU:C:1987:275; Judgment of 17.09.1997, Case C-54/96 Dorsch Consult Ingenieurgesellschaft $m b H$ v. Bundesbaugesellschaft Berlin mbH, ECLI:EU:C:1997:413; Judgment of 6.07.2000, Case C-407/98, Katarina Abrahamsson and Leif Anderson v. Elisabet Fogelqvist, ECLI:EU:C:2000:367.

4 Damages Directive, Art. 1(2). 
clearly whether other enforcement bodies can be granted powers that might clash with public enforcement (taking into account the EU paradigm that there is no effective private enforcement without effective public enforcement). ${ }^{5}$ Furthermore, there is a crucial requirement that this non-judicial system must be more effective that the judicial one and that judicial remedies must be provided. If that was not the case, such system can be considered contrary to the Damages Directive due to its ineffectiveness (failure of a Member State to provide an effective system for damages claims) and due to the lack of judicial protection, including an involvement of the Court of Justice of the European Union as the authority of last resort regarding the interpretation of EU law.

The Damages Directive does not require a specific structure or mode of operation of 'national courts'; that could be, in fact, contrary to the principles of subsidiarity or respect to the national identities of EU Member States. The only requirements given as far as national judiciaries are concerned can be seen in general principles of effectiveness and equivalence. The principle of effectiveness of enforcement is repeated several times in the Preamble of the Damages Directive. There are four aspects of effectiveness in this context:

(1) effective judicial enforcement in order to provide compensation to a harmed party: for example, Recital 4 demands ' (...) to have procedural rules ensuring the effective exercise of that right, Rec. 6 recalls that the aim of the Damages Directive is to ' $(\ldots)$ ensure effective private enforcement actions under civil law (...)';

(2) effective system of private enforcement as a whole (Recital 5: 'Actions for damages are only one element of an effective system of private enforcement $\left.(. . .)^{\prime}\right)$;

(3) the right to effective judicial protection (Recital 4: 'The need for effective procedural remedies also follows from the right to effective judicial protection as laid down in the second subparagraph of Article 19(1) of the Treaty on European Union (TEU) and in the first paragraph of Article 47 of the Charter of Fundamental Rights of the European Union. Member States should ensure effective legal protection in the fields covered by Union law');

(4) effective national enforcement of EU law (Article 4).

It must be noted that, in their literal meaning, the provisions of Article 4 of the Damages Directive require a rather low threshold of effectiveness of private enforcement of EU competition law: '(...)all national rules and procedures relating to the exercise of claims for damages are designed and applied in such a way that they do not render practically impossible or excessively difficult the exercise of the Union right to full compensation for harm caused by an

5 See for instance Opinion of AG Mazák in Case C-360/09 Pfleiderer AG v. Bundeskartellamt, ECLI:EU:C:2010:782. 
infringement of competition law'. A contrario, every situation which is at least a little better than 'practically impossible or excessively difficult' possibility for compensation of the harm can be considered to fulfil the harmonization requirement. Indeed, the Damages Directive recalls case-law and requires the right for full compensation of harm suffered from competition infringements. The effectiveness of private enforcement can be seen from two standpoints: substantive, that is, subjective right for compensation, and procedural, that is, an actual possibility to acquire such compensation. While 'substantive' effectiveness is easy to describe (definition of the extent of damages), 'procedural' effectiveness was described only by the lowest possible threshold. However, the threshold 'practically impossible or excessively difficult' is not absolute, and other requirements of the rule of law and right to a fair trial must be added, for example, it must be possible to execute the right to damages in reasonable time.

The principle of equivalence can be easily fulfilled by national legislation in this context too. The Damages Directive (Article 4) requires that '(...) national rules and procedures relating to actions for damages resulting from infringements of Article 101 or 102 TFEU shall not be less favourable to the alleged injured parties than those governing similar actions for damages resulting from infringements of national law'. It seems that a Member State can violate this provision by restricting private claims to cases of a breach of national competition law only, because it is hard to imagine that a reasonable legislator will develop a separate set of rules for the enforcement of national competition law and a separate set for EU competition law. If the Member State decides to develop rules for the enforcement of EU competition law only, the requirement of equivalence is fulfilled too. A situation where a Member State excludes EU law from private enforcement rules was not observed.

In the context of 'effectiveness' and 'equivalence', there is a question whether a Member State can design private enforcement rules for follow-on actions only. This problem arose in Bulgaria where the Supreme Court of Cassation stated that civil courts should refuse to hear a case for damages unless it was already examined by the NCA and the latter had found that a violation of competition law had been committed. ${ }^{6}$ Although this rule is not part of Bulgaria's statutory law, lower courts shall obey it (Petrov, 2017, p. 32-33). Regulation No. 1/2003 refers to the power of national courts to rule on violations of Article 101 and 102 TFEU, yet it does not stipulate in which phase this can be done. Therefore, if domestic law asks for prior investigation by a NCA, before the issuance of a final decision of the court on damages, this does mean a violation of the principles of effectiveness and equivalence

${ }^{6}$ Ruling No. 520 of 28.07.2014 in case No. 4004/2013 of the Supreme Court of Cassation, Commercial Division, $2^{\text {nd }}$ Chamber. 
per se. ${ }^{7}$ Furthermore, the Damages Directive itself requires that the relevant decision of the NCA shall be binding or constitute evidence of the violation, so why would the court rule before the NCA, risking that the NCA decides otherwise?

\section{Specialization of courts - general observations}

When implementing the Damages Directive, the question of creating (or assigning) special courts dealing with competition cases became part of legislative proposals in several CEE EU countries. When analysing the specialization of courts, two situations must be distinguished: (1) a specialized court or panels of the court or group of them that hold exclusive powers (specialization) to deal with certain types of cases, (2) specialized judges, that is, judges that are experts in a specific field of law, notwithstanding specialized powers of the court itself. There are different models of specialization of courts in Europe:

(1) concentration of cases, that is, the mechanism through which one or more courts in specific territories, on the basis of legal provisions or through agreements between courts, are allocated the exclusive competence to deal with certain categories of cases;

(2) allocation of specialized judges to different courts in the State's territory;

(3) cooperation between courts, for example, by transferring groups of pending cases from one court to another (Mak, 2008, p. 2).

Generally, arguments on efficiency, expertise and uniformity of specialized courts are given in favour of court specialization. However, an efficient and expert judge sitting at a specialized court does not imply an effective judicial system (Ginsburg and Wright, 2013, p. 793-795), because a small court with very few cases and few judgments can be considered less effective compared to a 'generalist' court dealing with the bulk of cases. Hence, balancing between specialization and a general scope of courts is crucial. Another point of view takes into account the supply-demand relationships of public policies. Under this approach, specialized courts reflect a special demand of the public, which is

\footnotetext{
7 'Per se' must be stressed in this context. Because in fact this approach can entail into massive violation of rights of harmed party. If there is a legal requirement of previous decision of a NCA, the NCA must be obliged to investigate and decide every case in which damages claims have been brought forward. On the other hand, the NCA can claim that this requirement can undermine its independence and it shall follow the public interest only. Nevertheless, there is a close relationship between effective private enforcement and public interest, as will be discussed later on.
} 
then answered by special attention of public authorities that create specialized courts filled by judges with expert training in specific legal areas (such as family courts, labour courts) (Barendrecht, Kamminga, and Verdonschot, 2008, p. 13).

Specialization and centralization of specialized courts shall be balanced with territorial diffusion of courts, because one of the understandings of the principle of access to justice can be read as the requirement for timely decision-making in a geographically nearby court. Therefore, balancing of territoriality and specialization takes into account two factors:

(1) the nature of cases: territorial and generalized courts can handle simple cases, while centralized and specialized courts can focus on more complex cases;

(2) the frequency of cases: frequently occurring types of cases can be dealt with most efficiently through territorial jurisdiction, since there are multiple courts dealing simultaneously with cases occurred in diverse regions; infrequent cases can be effectively handled by centralized/specialized court.

When combining these factors, Mak (Mak, 2008, p. 2) formulates the following combinations of territorial distribution and functional specialization of courts:

(1) simple and often occurring cases, for instance general contract disputes and simple criminal cases, are dealt with by general and territorially distributed courts (courts of first instance);

(2) complex and often occurring cases, for instance labour law cases and commercial law cases, are dealt with by specialized but territorially distributed courts;

(3) simple and sporadically occurring cases, for instance 'mass collective actions' and big criminal law cases are dealt with by a specific court with general jurisdiction;

(4) complex and sporadically occurring cases, for instance business law cases and intellectual property law cases, are dealt with by a small number of specialized courts.

Although Mak analysed the judiciary systems of Germany, France and the Netherlands, that is, countries territorially larger and more populous than the majority of CEE EU Member States, general observations can be applicable. Competition cases can be considered more complex and their occurrence is quite low.

Therefore, territorial-functional balancing can point to a small number of specialized courts. Several other factors can be found that speak in favour of assigning specialized/ centralized courts, for instance the probability of advice of specialized lawyers (often concentrated 'around' a particular court), 
possibility of collective actions (if available in a particular country), problematic territorial allocation and forum shopping (due to diversity of infringers and/or harmed parties), hard to estimate overall damage (in case the powers of the court are defined by value of the case).

This specialization can be acquired either by creating a 'specialized' court or by the specialization of one or more existing courts. Due to different models of judiciary systems, competition cases can be dealt with, in the first instance, by:

(1) general courts - all cases are dealt with by a lower court in the first instance;

(2) general courts, but more complex cases are dealt with by a higher court in the first instance;

(3) specialized courts, for instance commercial, competition or consumer courts;

(4) every possible combination of the aforementioned models.

The specialization of courts can bring also certain disadvantages. Their first group constitutes a counterpart to the aforementioned advantages: effectiveness of specialized courts $v s$ unbalanced effectiveness of the judiciary; uniformity and stability $v s$ conservatism; expertise $v s$ less expertise in other areas. A different level of effectiveness of specialized courts, as compared to general courts, can represent an imbalanced judicial system as a whole. Uniformity of case-law and procedures can overtake incentives for new approaches and positive 'deviations'. Finally, high expertise of judges can make them loose perspective, when they become too focused on a particular area of law without taking into account the development and dynamics of the legal system as a whole (Cf. Ginsburg and Wright, 2013, 802-806). The selection of judges for the court, as well as for a particular case can be problematic too. A judicial appointment to a specialized court does not make a judge an expert in the field of the specialization of the court. Hence, only experts can be selected for specialized courts, or relevant training must be provided to judges after their appointment. Indeed, an appointment to a specialized court cannot be considered punishment or a form of sanction (there is a notorious case in Slovakia when the, at that time, chairman of the Supreme Court, Stefan Harabin, harassed his opponents, moved a long-serving criminal judge to an administrative panel as a form of revenge and made very derogatory speeches regarding administrative judges). ${ }^{8}$ If a specialized court has a rather low number of judges, random selection of the judge for a particular case, from that rather narrow pool of judges, can develop into more of a regular

8 For instance ' $(\ldots)$ he can do pensions, there he cannot cause damage (...), since he is and engineer, he can work in boiler room (...)' [online] http://www.sudcovia.sk/sk/dokumenty/ externe/115-gavalec-reakcia (12.07.2017). 
pattern than random selection, and thus the impartiality and neutrality of the court can be undermined.

\section{Specialization, centralization and generalized approach in CEE Member States}

According to the current state of legislation, following models and approaches can be observed in CEE Member States regarding first-instance courts competent to deal with private enforcement cases:

(1) single specialized court - in Lithuania, Romania, Slovakia and, via the draft law, in Latvia;

(2) 'higher' courts competent in the first instance - Czech Republic, Poland and Slovenia;

(3) specialized commercial courts - Croatia;

(4) jurisdiction is split between 'lower' and 'higher' courts depending on the amount of the claim - Bulgaria and Hungary;

(5) no further specialization - Estonia.

None of the CEE Member States created a special court empowered to handle competition cases. Although a specialised competition court exists in Poland (Sąd Ochrony Konkurencji i Konsumentów, hereinafter SOKiK), dealing with appeals to administrative decisions issued by the Polish competition authority (Prezes Urzędu Ochrony Konkurencji i Konsumentów), the Polish legislator did not choose to grant SOKiK the power to deal with private enforcement claims (Piszcz and Wolski, 2017, p. 216).

In Slovakia, the District Court Bratislava II has had the exclusive power to deal with all competition law disputes even before the transposition of the Damages Directive. By mere coincidence, the new Civil Disputes Code ${ }^{9}$ came into force in July 2017 and this assignation was confirmed. The District Court Bratislava II (Okresný súd Bratislava II) cannot be considered an expert court in business matters, or other types of more complex cases that require also an economic point of view or, at least, the capacity to understand them. This court is a generalist court and competition matters are its only possible specialisation (for details see Blažo, 2017, p. 251). Other 'specialisations' similar to competition matters (for instance, patents and intellectual property rights, abstract revision of consumer contracts) are entrusted to other specific courts. Hence, none of these courts can benefit from synergies arising from the accumulation of experiences in complex business-consumer questions

9 Act No. 216/2016 Coll. Civil Disputes Code is one of the outcomes of the long-lasting reform of Slovak civil law; it replaced Act No. 99/1963 Coll. Civil Court Proceeding Code. 
involving economic issues. Such synergies cannot be achieved at the second instance either. Decisions of district courts are reviewed by regional courts, so competition cases are to be reviewed by the Regional court in Bratislava. However, what seems to be another coincidence, this regional court reviews also the decisions of the Slovak competition authority in the capacity as an administrative court. Administrative, civil, commercial and penal judges and panels are separated within the courts and so private law competition cases will be handled by other judges (that is, not civil law judges) who can have some experience from administrative competition cases. Either way, the quality of judicial review in competition matters and the approaches and expertise showed by administrative judges (that also handle all types of administrative revision cases) is currently dubious in Slovakia because the reasoning presented by judges is not very persuasive and in some cases, Slovakian judgments in administrative cases are contrary to settled case-law in European competition law (Cf. Kalesná, 2016; Fodorová, Šabová and Lukáčová, 2013; Šabová, 2016; Blažo, 2013). Hence, the specialisation of courts for competition matters in Slovakia can avoid problems with territorial jurisdiction and enable more focused training for judges. However, it does not facilitate synergies arising from experience of judges dealing with complex business and consumer cases. It must also be noted that due to the usual career steps taken by judges, the majority of judges in district courts are at the beginning of their careers, judges who do not have the capacity to take the next step in their career or for other reasons decide not to pursue their professional career. It was decided in Romania and Lithuania to assign exclusive powers to deal with competition matters to one of their higher courts, the Bucharest Tribunal Court of Appeal (Curtea de Apel Bucuresti) ${ }^{10}$ and the Vilnius Regional Court (Vilniaus Apygardos Teismai) ${ }^{11}$ respectively. Both of these courts were selected because of the greater experience of their judges (Micrea, 2017, p. 238-239, Mikelènas and Zaščiurinskaitè, 2017, p. 184). Moreover, synergies from experiences gathered in dealing with other complex cases can occur. In particular, the Vilnius Regional Court has also exclusive competences in certain other complex and specific legal fields, for instance patents and trademarks regulation (Mikelėnas and Zaščiurinskaitė, 2017, p. 184). A similar approach was suggested in Latvia where its draft legislation designates the City of Riga Latgale District Court (Rĭgas pilsētas Latgales priekšpilsētas tiesa) as the only court dealing with competition cases. However, judges of this court are not currently trained in competition law, and their training is only expected in future (Jerneva and Druviete, 2017, p. 160).

\footnotetext{
10 Exclusive competence created by the transposition of the Damages Directive.

11 Already from 2004.
} 
Granting exclusive powers to deal with competition cases to one court has also its opponents. In territorially larger and more populous countries, particularly Poland and Romania, limited access to justice due to large distances to the competent court can constitute a ground for objections (for this discussion for Poland see Piszcz and Wolski, 2017, p. 215; and for Romania see Mircea, 2017, p. 239). On the other hand, it is unlikely for harmed parties to claim damages without legal assistance from a specialized lawyer, and this type of claim does not require the personal presence of the parties before the court (comparing to, for instance, family matters, small civil claims). Therefore, centralization in competition matters does not seem to be a serious hurdle for effective private enforcement.

Entrusting 'higher' courts, that is courts that are normally appellate but still generalist courts, is a compromise between specialization and a generalist approach. It can be expected that judges sitting at such courts have certain judicial experience and also certain expertise in complex matters involving also questions of economic effectiveness, quantification of harm etc. This approach was taken in Poland (regional court - sqd okregowy) and Hungary (regional courts - törvényszék) and is under consideration in the Czech Republic (regional courts - krajské soudy) (Petr, 2017, p. 88). In Slovenia, district courts (okrožna sodišča), which are responsible for competition cases, are 'higher' than local courts (okrajna sodišča), albeit they are not appellate courts. When selecting a 'group' of courts that shall deal with competition cases, specialization of commercial courts seems to be a reasonable option. Such courts fulfil, on one hand, the request for territorial proximity but, on the other hand, they are still specialized and can benefit from synergies produced by experience of their judges accumulated in other complex business matters. This approach was taken in Croatia where commercial courts ${ }^{12}$ deal with a wide range of business matters, including business disputes, maritime disputes, bankruptcy matters, intellectual property cases or registration of companies (Butorac Malnar, 2017, p. 61).

Regarding the training of judges in competition law it must be noted that 11 district courts in Slovenia, 8 regional courts and the Metropolitan court in Prague (Městský soudv. Praze) in the Czech Republic and 7 commercial courts in Croatia allow certain targeted training and education. However, in the case of the 19 regional courts and the Budapest-Capital Regional Court (Budapest Környéki Törvényszék) in Hungary as well as more than 40 regional courts in Poland, this training will be more challenging and the benefit deriving from the concentration of experiences can be lost.

12 Commercial courts are organized in two instances: in the $1^{\text {st }}$ instance, 7 commercial courts; in the $2^{\text {nd }}$ instance, the High Commercial Court of the Republic of Croatia (Visoki trgovački sud Republike Hrvatske). 
In Estonia and Bulgaria the transposition of the Damages Directive did not affect the judicial system and no special court or group of courts was chosen to deal with competition cases. Furthermore, the situation is more complex in Bulgaria because of the split of competences between different levels of the courts depending on the amount of the claim: claim value up to BGN 25,000 (approx. EUR 12,500) should be reviewed by a district court (районен $c ъ d)$, whereas a provincial court (окръжен съд) should examine claims above this threshold. Article 365(5) of Code on Civil Procedure stipulates that provincial courts should follow the procedure for commercial disputes when deciding cases related to cartel agreements, decisions and concerted practices, concentrations, unfair competition, and the abuse of a monopolistic or dominant position. However, this cannot be read as exclusive competence of provincial courts in competition matters, ${ }^{13}$ but merely as the setting of procedural rules if the case is handled by a regional court (for details see Petrov, 2017, p. 34-35). Apart from different procedural rules at district courts and provincial courts, the complexity of the system itself can be confusing for prospective claimants (and practical questions of choosing applicable procedural court rules, that is, civil or commercial), especially in the situation when the court is allowed to estimate the amount of damages. This structure does not, therefore, seem to be suitable for effective competition claims and can theoretically (and maybe later also practically) lead to chaotic situations when claims of different claimants will be handled not only by different courts from the territorial point of view, but also of a different level under different procedural rules.

\section{Relationship between courts and NCAs}

The European Commission can intervene in both types of court proceedings - judicial revision of administrative decision issued by NCAs and in civil claims procedures. Moreover, it can act as amicus curiae in criminal cases if European competition rules are applied. The main purpose of the power of the European Commission as amicus curiae is to maintain uniform application of EU law. Although the Commission has broad discretion whether to be, or not to be involved in a court proceeding, it can be discussed whether it has a duty to act if uniform application of EU competition law is in question and whether it is possible to file an action against the Commission's failure to act.

13 Ruling No. 3103/2016 of the Sofia Court of Appeals (Софийски апелативен съд) on civil case No. 4102/2016. 
Another motive of the Commission can be seen in cases where it already acted as a competition authority.

Similar motives can be seen in establishing the power of NCAs to act as amicus curiae in purely national cases, that is, cases outside the reach of Regulation No. 1/2003. In this context, a NCA can act as amicus curiae in general (provide its options and explanations to every possible aspect of the case), or its powers are restricted to questions of the quantification of harm. Hungarian and Slovak law explicitly introduce the NCA as 'general' amicus curiae. It must be, however, distinguished from a court's power to ask, or to order the cooperation of other subjects of law, including state authorities. Furthermore, it shall be distinguished from the position of a 'third party' or intervenient, that is, a party that shall show its legal interest in a particular case.

Both Hungarian and Slovak rules on amicus curiae are shaped under the model of the European Commission, which is more focused on information rights of the competition authority and notification duties of a court and the authority's right to be heard before a court, than on the responsibilities of the competition authority in this context. In the Hungarian model, the court is obliged to interrupt its proceeding while the authority takes 'surveillance action'. In Slovakia, the law is silent on this question, although a decision of the competition authority can serve as a decision in a preliminary question, and so it can give grounds for an interruption of the court's proceeding. The Act on protection of economic competition stipulated very carefully that the Slovak competition authority has discretion whether or not to provide guidance to the court regarding the quantification of harm, however this power of the competition authority is described in a separate provision of the Slovak competition act ${ }^{14}$ (Article 22(1)(n)).

Slovenian legislation went even further and introduced 'international' cooperation between courts and competition authorities (Article 62k ZPOmK-1). In other words, a court may ask NCAs of other Member States for their opinions and the Slovenian competition Agency may provide assistance to national courts of other Member States (Vlahek and Podobnik, 2017, p. 272). However, this form of 'on demand' cooperation is not amicus curiae stricto sensu.

According to the wording of respective laws, amicus curiae is always defined as a power of a competition authority, with a corresponding duty of the court to allow the authority to present its opinion. It seems, therefore, that the competition authority has no duty to act as amicus curiae. However, general duties or responsibilities of the competition authority, that is, to protect competition,

14 Act No. 136/2001 Coll. on Protection of Economic Competition and Amending Act of the Slovak National Council No. 347/1990 Coll. on Organization of Ministries and Other Central Bodies of State Administration of the Slovak Republic as Amended as amended. 
to enforce competition law or to provide competition advocacy, can suggest otherwise. ${ }^{15}$ Competition authorities usually enjoy certain discretion whether to launch an investigation or proceeding on the basis of their prioritisation policies, and this principle is applicable to amicus curiae also. Prioritisation and discretion of a competition authority cannot be replaced by arbitrariness - the authority cannot overlook a manifest and harmful violation of competition law due to principles of the rule of law, good administration of public affairs, equality and justice. An 'inaction' of a competition authority in such cases can be deemed illegal, and a harmed party can claim damages from the State stemming from such failure to act. Similar principles seem to be applicable to amicus curiae. The decision of a competition authority whether to intervene in a given civil proceeding must be based on objective criteria, rather than on a subjective assessment. The competition authority shall take into account criteria such as relevance of the dispute for competition law enforcement as a whole, relevance of the opinion of the authority due to, for instance, facts and legal opinions represented by the parties, necessity of public enforcement in the case, etc. Moreover, with respect to stand-alone actions, private disputes can serve as a source of information for public law enforcement. These principles and responsibilities of NCAs can appear to work well on paper and in theory, but a real action for damages caused by inaction of a NCA, including refusal to act as amicus curiae, is quite a long shot. This responsibility is, thus, more of a political one, as accountability for the condition of competition enforcement in a particular country, which is a topic for possible further research.

\section{Conclusions}

The Damages Directive does not require a specific judicial structure to apply for damages claims for competition law infringements, and so Member States have full discretion in shaping their judicial structure, including the

15 For instance, in the Czech Republic, according to Act No. 273/1996 Coll. on the Scope of Competence of the Office for the Protection of Competition as amended, the Office for the Protection of Competition is a central administrative body, its purpose is to maintain and protect competition against its prohibited restriction $(\$ 1(1))$ and the Office creates conditions for maintenance and protection of competition ( $\$ 2 \mathrm{a})$ ); in Latvia according to Cabinet Regulation No. 795 adopted 29 September 2008 (By-law of the Competition Council as amended), the Competition Council, (...), shall implement State policy in the matters of development and protection of competition (para. 2); in Hungary under Act No. LVII of 1996 Art. 33 (1) the Hungarian Competition Authority (...) is responsible for competition supervision (...); in Slovakia, the Antimonopoly Office is under Act No. 136/2001 Coll. on protection of economic competition, a central body of state administration for protection and promotion of competition $(\S 14(2)$ ). 
specialization or not of their courts or judges. Due to the specific character of private competition law enforcement claims and their rarity, it seems that for the proper performance of justice and access to justice, expertise and preparedness of courts is more relevant than their territorial proximity (to the victim). The necessity to educate judges has been stressed also by the Supreme Court of the Slovak Republic in the so-called 'Highway cartel' case, ${ }^{16}$ where the court itself questioned the ability of Slovak courts to properly decide on competition cases. ${ }^{17}$

Specialisation of courts, particularly in smaller economies, cannot be a process of random selection of a given court without assessing that its ability to deal with such cases is equivalent to a generalist court. Accumulating complex cases, which also involve an economic assessment or context, in the hands of one or a small number of courts seems to be a more suitable compromise promoting specialisation and limiting its disadvantages - hence the concept of commercial courts (Croatia) or choosing only one court that is already dealing with similar complex cases (Lithuania, Romania). However, every specialisation of courts requires the solution of a potential conflict of competences in 'mixed' cases, that is, in cases where the application of competition law is only a preliminary or partial issue (for instance, business or consumer disputes where a competition law violation is used as a defence invoking the nullity of a contract, on which a claim for payment is based).

161 Sžhpu/1/2009, 30.12.2013.

17 ' (...) the panel of the supreme court must note (...) that the case in issue falls into particularly specialized agenda that is quite new for the judges and that is due its character factually and legally substantially compacted and almost always connected to international element, legislatively stemming from communitarian regulation (primary and secondary one) that requires high level of knowledge of not only foreign-language scientific literature as well as decision-making activity of the Commission and of the CJ EU, which decisions are accessible in Slovak language for the judges of the Supreme Court of the Slovak republic only in limited extent. Regarding aforementioned, one must note particular character of competition law which is exceptional not only by connecting objective law with economic theory, but also by implanting economic notions into legal order which then become legal rules by long-term legal practice, while only few legal areas use economic institutes in such depth such as competition law (...) This character of agenda, showing also rising level of variability and flexibility of anticompetitive practices, undoubtedly requires high specialization of judges with rising accent on decision-making tier, necessity of their systematic and permanent education as well as professional capacity of judicial personal in this area, which is unfortunately still permanently missing in the conditions of the Slovak Republic. Without deep and firm experience of judges, in this particular agenda, it is not possible due to Art. 101 to 106 TFEU secure fulfilment of union competition rules by issuing broadly acceptable and authoritative judicial decisions. Therefore the panel agrees with complaints of the Commission that the Slovak judicial system does not show stability of panels trying competition agenda, and not even on a such high level as the Supreme Court of the Slovak Republic, it is still not able unity of its decision-making activity in this area (...) what undoubtedly endangers competition on Slovak market'. 
Cooperation between courts and NCAs in private enforcement issues (amicus curiae or quantification of harm) is more a question of policy of a given competition authority, its activism and responsibility for the competition environment in its country as a whole. Therefore, even though NCAs enjoy discretion and procedural autonomy, these must be understood as features of their independence. Moreover, these actions must follow a straightforward policy pattern. Thus NCAs shall be prepared to be policy makers also in private enforcement of competition law.

\section{Literature}

Barendrecht, M., Kamminga, P. and Verdonschot, J. H. (2008). Priorities for the Justice System: Responding to the Most Urgent Legal Problems of Individuals. TISCO Working Paper Series on Civil Law and Conflict Resolution Systems No. 001.

Blažo, O. (2017). Slovakia. In: A. Piszcz (ed.), Implementation of the EU Damages Directive in Central and Eastern European Countries. Warsaw: University of Warsaw, Faculty of Management Press.

Blažo, O. (2013). Nullum crimen, nulla poena sine lege a generálne klauzuly v prípadoch zneužitia dominantného postavenia [Nullum crimen, nulla poena sine lege and general clauses in cases of abuse of dominant position]. Justičná revue 65(4).

Butorac Malnar, V. (2017). Croatia. In: A. Piszcz (ed.), Implementation of the EU Damages Directive in Central and Eastern European Countries. Warsaw: University of Warsaw, Faculty of Management Press.

Ginsburg, D. H. and Wright, J.D. (2013). Antitrust Courts: Specialists Versus Generalists, Fordham International Law Journal 36(4), 788-810.

Jerneva, J. and Druviete, I. (2017). Latvia. In: A. Piszcz (ed.) Implementation of the EU Damages Directive in Central and Eastern European Countries. Warsaw: University of Warsaw Faculty of Management Press.

Ježová, D. (2013). Prejudiciálne konanie pred Súdnym dvorom EÚ, Žilina.

Kalesná, K. (2016). Generálne klauzuly v sútažnom práve [General clauses in competition law], Právny obzor 99(2), 79-88.

Mak, E. (2008). Balancing Territoriality and Functionality; Specialization as a Tool for Reforming Jurisdiction in the Netherlands, France and Germany. International Journal For Court Administration 1(2), 2-9.

Mikelénas, V. and Zaščiurinskaité, R. (2017). Lithuania. In: A. Piszcz (ed.), Implementation of the EU Damages Directive in Central and Eastern European Countries. Warsaw: University of Warsaw Faculty of Management Press.

Mircea, V. (2017). Romania. In: A. Piszcz (ed.), Implementation of the EU Damages Directive in Central and Eastern European Countries. Warsaw: University of Warsaw Faculty of Management Press.

Miskolczi Bodnár, P. (2017). Hungary. In: A. Piszcz (ed.), Implementation of the EU Damages Directive in Central and Eastern European Countries. Warsaw: University of Warsaw Faculty of Management Press. 
Pärn-Lee, E. (2017). Estonia. In: A. Piszcz (ed.), Implementation of the EU Damages Directive in Central and Eastern European Countries. Warsaw: University of Warsaw Faculty of Management Press.

Petr, M. (2017). Czech Republic. In: A. Piszcz (ed.), Implementation of the EU Damages Directive in Central and Eastern European Countries. Warsaw: University of Warsaw Faculty of Management Press.

Petrov, A. (2017). Bulgaria. In: A. Piszcz (ed.), Implementation of the EU Damages Directive in Central and Eastern European Countries. Warsaw: University of Warsaw Faculty of Management Press.

Piszcz, A. and Wolski, A. (2017). Poland. In: A. Piszcz (ed.), Implementation of the EU Damages Directive in Central and Eastern European Countries. Warsaw: University of Warsaw Faculty of Management Press.

Šabová, Z., Fodorová, K. and Lukáčová, D. (2013). Recent Developments in Slovak Competition Law - Legislation and Case Law Review, Yearbook of Antitrust and Regulatory Studies, 6(8), 223-243.

Šabová, Z. (2016). Zásady správneho trestania v sútažnom práve [Principles of administrative punishment in competition law]. In: M. Lenhart, I. Hapčová, J. Hamulák (eds), Zborník príspevkov z konferencie Bratislavské právnické fórum 2016. Comenius University in Bratislava, Faculty of Law.

Stehlík, V. (2005). Teoretické aspekty pojmu „soud“ v řízení o předběžné otázce podle čl. 234 SES na pozadí judikatury ESD, Právník 7, 704-739.

Stehlík, V. (2006). Řizení o předběžné otázce v komunitárním právu, Olomouc.

Steiner, J. and Woods, L. (2009). EU Law, Oxford.

Vlahek, A. and Podobnik, K. (2017). Slovenia. In: A. Piszcz (ed.) Implementation of the EU Damages Directive in Central and Eastern European Countries. Warsaw: University of Warsaw Faculty of Management Press. 